\title{
Enhanced bacterial phagocytosis by peripheral blood monocytes in rheumatoid arthritis
}

\author{
M. M. STEVEN,$^{1}$ S. E. LENNIE, ${ }^{1}$ R. D. STURROCK, ${ }^{1}$ AND C. G. GEMMELL ${ }^{2}$ \\ From the ${ }^{1}$ Centre for Rheumatic Diseases, Glasgow, and the ${ }^{2}$ Department of Bacteriology, Glasgow Royal \\ Infirmary
}

SUMMARY To assess the functional state of peripheral blood monocytes in rheumatoid arthritis, we have measured phagocytosis of Staphylococcus aureus and Proteus mirabilis in 48 patients and 28 controls. Using radiolabelled bacteria preopsonised in normal human serum we have demonstrated significantly enhanced uptake of both organisms by patients' monocytes: (Median \% uptake Staph. aureus: patients $=35 \cdot 8$; controls $=19.3 ; \mathrm{p}<0.001$. Median $\%$ uptake $P$. mirabilis: patients $=32 \cdot 3$; controls $=19 \cdot 8 ; p<0 \cdot 01$.) These results indicate that patients' monocytes exist in an activated state, which may be important in the pathogenesis of rheumatoid arthritis.

Cells of the mononuclear phagocyte series (macrophages MO) are thought important in the pathogenesis of chronic inflammatory diseases including rheumatoid arthritis. ${ }^{1}$ In addition to secreting proteolytic enzymes capable of cartilage destruction $^{2}$ MO also secrete factors capable of stimulating other cells to release inflammatory and proteolytic substances. ${ }^{3}$ In association with enzyme secretion other MO activities, including adherence, spreading, bacterial phagocytosis, and bacterial and tumour cell killing, are increased on stimulation. ${ }^{4}$ Type A synovial cells, which exhibit macrophage-like features, ${ }^{5}$ also secrete proteolytic enzymes. ${ }^{6}$ Previous workers who examined the phagocytic capacity of polymorphonuclear leucocytes (PMN) from peripheral blood and synovial cavity ${ }^{7}$ demonstrated reduced phagocytosis by synovial fluid PMN of RA patients and reduced phagocytosis by normal peripheral blood PMN incubated in RA synovial fluid. Studies of MO phagocytosis in RA patients have revealed conflicting results. Using different techniques 3 authors found no difference between MO phagocytic activity (PA) in uncomplicated RA patients and controls, ${ }^{8-10}$ but Hoch and Schur found enhanced phagocytosis of IgG coated sheep red blood cells by RA patients' monocytes. ${ }^{11} \mathrm{~A}$ pilot study in our laboratory indicated enhanced bacterial phagocytosis and killing by RA MO, ${ }^{12}$ so we extended our study to confirm this work.

Accepted for publication 5 September 1983.

Correspondence to Malcolm Steven, MRCP, Centre for Rheumatic Diseases, 35 Baird Street, Glasgow, Scotland.

\section{Materials and methods}

Forty-eight patients with classical or definite RA were studied, and 28 normal volunteers served as controls. Ten patients and 11 controls were tested on more than one occasion, making a total of 58 patients and 52 controls. The female:male ratio of patients was $3: 1$ and of controls $1 \cdot 7: 1$. The median age for patients ivas 54 years and for controls 41 . Clinical details of the patients are shown in Table 1. The physician's assessment of disease activity was made by considering the combination of morning stiffness,

Table 1 Details of RA patients

\begin{tabular}{lccl}
\hline & $n$ & Range & Median \\
\hline Age (years) & 48 & $24-74$ & 54 \\
Duration of disease & 48 & $1-40$ & $11 \cdot 5$ \\
Haemoglobulin (g/dl) & 48 & $8 \cdot 1-16 \cdot 8$ & $11 \cdot 4$ \\
ESR & 48 & $3-132$ & 56 \\
Rheumatoid factor & & & \\
Currently < 1:32 & 18 & & \\
Currently > 1:32 & 19 & & \\
Treatment & & & \\
Analgesics only & 3 & & \\
NSAID & 29 & & \\
NSAID + 2nd line & 6 & & \\
NSAID + steroid/cytotoxic & 10 & & \\
Disease activity (physician's assessment) & & & \\
Quiescent & 4 & & \\
Moderate & 18 & & \\
Severe & 26 & & \\
\hline
\end{tabular}

NSAID $=$ Nonsteroidal anti-inflammatory drugs. 2 nd line $=$ gold, penicillamine, or levamisole 
articular index (Ritchie), and ESR, and a global assessment was arrived at. All experiments were carried out on hospital inpatients, and blood samples were taken at the same time each day for phagocytic experiments.

Phagocytic activity (PA) was measured by a modification of the method of Peterson et al. ${ }^{13}$ Briefly Staphylococcus aureus (NCTC 51330) and Proteus mirabilis (laboratory strain) maintained in laboratory culture were radiolabelled by inoculation into Mueller-Hinton broth (Oxoid Ltd, Basingstoke, England) containing $20 \quad \mu l{ }^{3} \mathrm{H}$-thymidine (25 $\mu \mathrm{Ci} / \mathrm{mmol}$ specific activity, Radiochemical Centre, Amersham, England.) After overnight culture at $37^{\circ} \mathrm{C}$ the bacteria were washed and resuspended at 1 $\times 10^{9}$ colony forming units $/ \mathrm{ml}$ by a spectrophotometric method. Bacteria $\left(1 \times 10^{8} / \mathrm{ml}\right)$ were then opsonised for 15 minutes in normal human serum in Hanks's balanced salt solution with $0.1 \%$ gelatin (gel HBSS) at a serum concentration previously shown to give optimal PA (Staph. aureus $20 \%$, P. mirabilis 50\%). Opsonised bacteria were spun and resuspended to the initial concentration in gel HBSS.

Peripheral blood monocytes were isolated from heparinised venous samples by a modification of the method of Boyum. ${ }^{14} 10 \mathrm{ml}$ of blood was mixed with 3 $\mathrm{ml}$ of $6 \%$ dextran and gravity sedimented for 45-60 min. Leucocyte rich plasma was layered on to Ficoll Hypaque (Pharmacia Ltd, Uppsala, Sweden) and centrifuged at $200 \mathrm{~g}$ for 10 minutes. The mononuclear cell layer was carefully removed, washed, counted, and resuspended to a final concentration of $5 \times 10^{6} / \mathrm{ml}$. Mononuclear preparations stained by Wright's and nonspecific esterase (Sigma, Poole) contained $25-35 \%$ monocytes on morphological criteria, and the proportion of monocytes was similar in patients and controls.

Opsonised radiolabelled bacteria $(0.1 \mathrm{ml})$ and mononuclear cells $(0.1 \mathrm{ml})$ were added to duplicate polypropylene vials and incubated with shaking for 15 minutes at $37^{\circ} \mathrm{C}$. Thereafter phagocytosis was terminated in one set of vials by the addition of phosphate buffered saline (PBS) at $4^{\circ} \mathrm{C}$. Duplicate vials were assessed for total bacterial radioactivity by the addition of $3 \mathrm{ml}$ scintillation fluid (Aquasol LKB Instruments Ltd, London, England) and counted on a liquid scintillation counter (A). The first set of vials meanwhile had the nonphagocytosed bacteria removed by differential centrifugation $(160 \mathrm{~g})$ and washing in PBS $\left(4^{\circ} \mathrm{C}\right) 3$ times. The final pellet of cells containing phagocytosed bacteria was counted after the addition of scintillation fluid as above (B). The uptake of bacteria was then calculated as:

$$
\% \text { Uptake test }=\frac{\mathrm{cpm} \mathrm{B}}{\mathrm{cpm} \mathrm{A}} \times 100 \%
$$

A further set of tubes containing only bacteria were similarly handled, giving a reading representing nonspecific bacterial aggregation and adherence to the tube (blank). PA was expressed as:

$$
\text { PA }=\% \text { uptake test - \% uptake blank. }
$$

In some experiments phagocytosis of Staph. aureus was measured after the addition of lysostaphin..$^{15}$ The result of some experiments using Staph. aureus rich in protein A gave unexpectedly high blank uptakes, and results where blank values were less than $20 \%$ were considered separately. Statistical analysis was performed by appropriate nonparametric tests. ${ }^{16}$

\section{Results}

Phagocytosis of Staph. aureus and P. mirabilis by MO of RA patients and controls is shown in Figs 1 and 2.

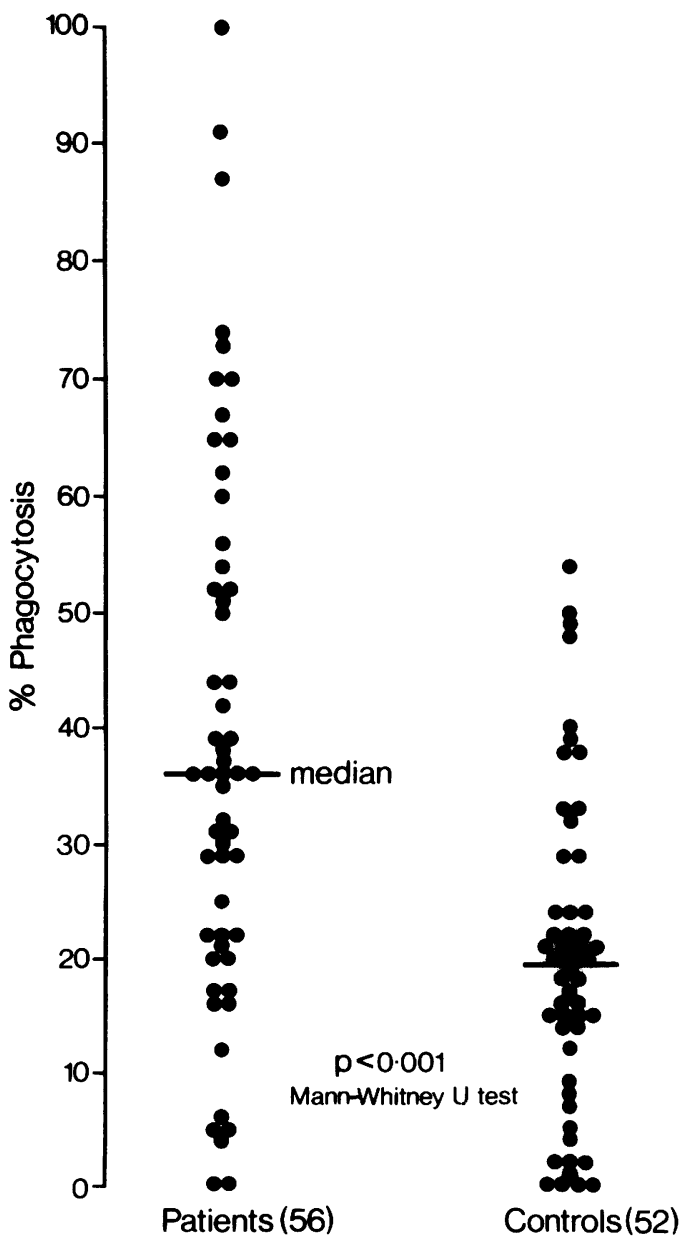

Fig. 1 Uptake of Staph. aureus opsonised in $20 \%$ normal human serum by monocytes from RA patients and controls. 


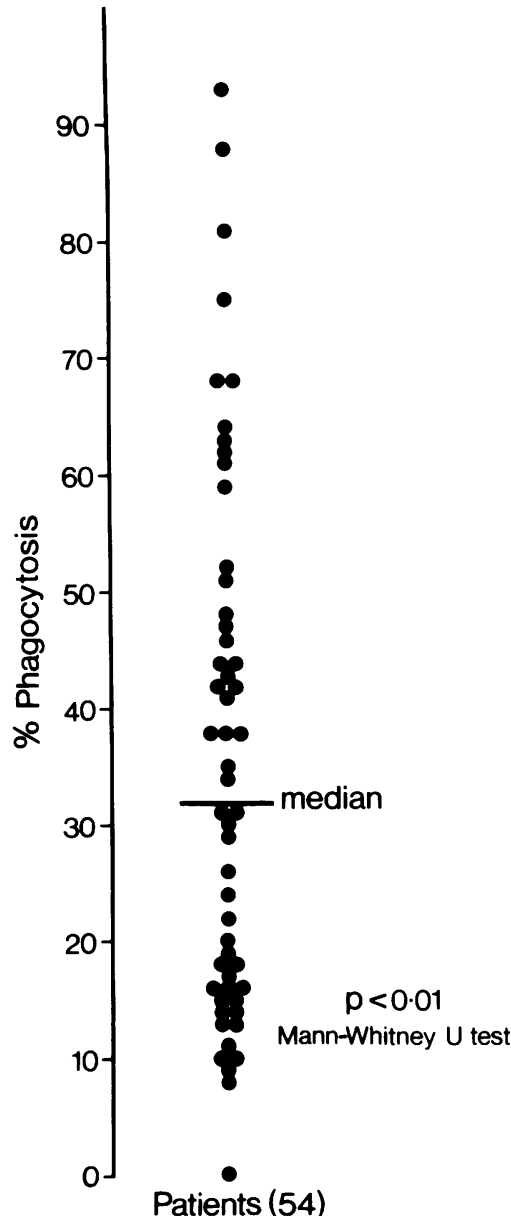

Fig. 2 Uptake of P. mirabilis opsonised in $50 \%$ normal human serum by monocytes from $R A$ patients and controls.

Highly significant increases in PA were seen in RA patients, and the results were not altered by the exclusion of Staph. aureus tests with blanks greater than $20 \%$. Since the sex ratios of patients and controls were different, MO PA was compared in men and women, but no significant differences were found (median \% phagocytosis Staph. aureus: men = $21.5 \%$, women $=28.9 \% p=$ NS, Mann-Whitney U test). A significant correlation was, however, seen between PA and age (Fig. 3), with increasing values with age. In view of some disparity in age between the patient and control groups a comparison of PA in the $30-60$ age group was specifically made. The patients' PA remained elevated compared with that of controls (median \% phagocytosis Staph. aureus: patients (39) $=35.9 \%$, controls $(36)=20.0 \%, p<0.005)$,

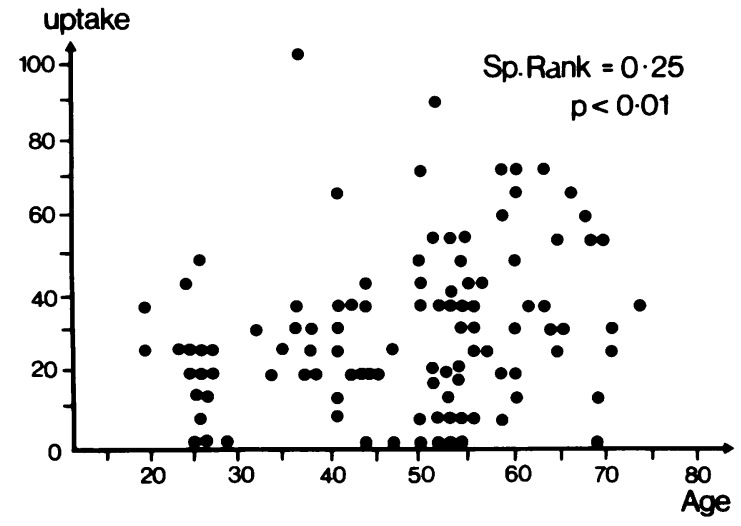

Fig. 3 Percentage uptake of Staph. aureus opsonised in $20 \%$ normal human serum correlated with age of patients or control.

Table 2 Phagocytosis versus disease activity and treatment

\begin{tabular}{|c|c|c|c|}
\hline & $n$ & $\begin{array}{l}\text { \% Phagocytosis } \\
\text { P. mirabilis } \\
\text { (median) }\end{array}$ & $\begin{array}{l}\text { Significance } \\
\text { (Mann-Whitney) }\end{array}$ \\
\hline \multicolumn{4}{|l|}{ Activity } \\
\hline Moderate & 19 & $40 \cdot 8$ & NS \\
\hline Severe & 25 & $32 \cdot 0$ & \\
\hline \multicolumn{4}{|l|}{ Treatment } \\
\hline \multirow{3}{*}{$\begin{array}{l}\text { NSAID } \\
\text { NSAID + 2nd line } \\
\text { NSAID + steroid/ } \\
\text { cytotoxic }\end{array}$} & 30 & $39 \cdot 4$ & \\
\hline & 6 & $23 \cdot 2$ & \\
\hline & 10 & $16 \cdot 1$ & vs. NSAID: $p=0.06$ \\
\hline
\end{tabular}

Mann-Whitney U test. PA of Staph. aureus and P. mirabilis were also significantly correlated $\left(\mathrm{r}_{\mathrm{s}}=0 \cdot 56\right.$, $\mathrm{p}<0.001$, Spearman rank correlation). The addition of lysostaphin resulted in a small reduction in PA values (mean reduction $=6 \cdot 6 \% \pm 1 \cdot 7,1 \mathrm{SD}, \mathrm{n}=9$ ), and the reduction in PA values was similar for patients and controls.

The patients' PA was then correlated with clinical parameters, but no correlation was seen with duration of disease, haemoglobin, ESR (Spearman rank), or seropositivity for rheumatoid factor (Mann-Whitney U test). Comparison with treatment and the physicians' assessment of disease activity (Table 2) showed non significant reductions of phagocytosis in severe disease and in the steroid/cytotoxic drug treated group.

\section{Discussion}

Contrary to 3 previous reports ${ }^{8-10}$ we have shown enhanced phagocytosis by peripheral blood mono- 
cytes from RA patients. In one study ${ }^{9}$ microscopical assessment of latex particle phagocytosis was used and in another ${ }^{8}$ microscopical assessment of the uptake of yeast opsonised by immunoglobulin and/or complement. In the latter study the numbers were small, but patients with RA complicated by cutaneous vasculitis had reduced complement mediated phagocytosis. Hurst and $\mathrm{Nuki}^{17}$ showed reduced PA in patients with systemic lupus erythematosus (SLE), a dise ase frequently associated with hypercomplementaemia and circulating soluble immune complexes. In another study serum from patients with SLE and RA depressed the phagocytosis of yeast by normal monocytes, ${ }^{18}$ and Svensson and colleagues suggested that immune complexes in the sera of SLE patients interfered with the opsonisation process. ${ }^{19}$

Microscopical assays are difficult to perform and subject to interobserver error, as it may be difficult to decide if a yeast cell is on the cell surface or truly phagocytosed. As previously reported ${ }^{15}$ the addition of lysostaphin showed that $90 \%$ of bacterial uptake was the result of ingestion rather than adherence to the cell surface by our technique. Furthermore the results seen with staphylococci were parallelled by those with proteus, an organism which is much less likely to exhibit nonspecific adherence. In another study ${ }^{10}$ a nonsignificant increase in the uptake of killed ${ }^{125}$ I labelled Staph. albus and shigella by RA monocytes was recorded. However, the uptake of live ${ }^{3} \mathrm{H}$-thymidine labelled Staph. albus did not differ from normal in 6 RA patients. No details of opsonisation or measurement of phagocy tosis are given in that study, and it is difficult to make a comparison with the present work.

Increased binding and phagocytosis of IgG labelled sheep red blood cells has been demonstrated in RA patients, ${ }^{11}$ and in addition it was noted that steroid treated patients had significantly lower uptake than patients on other treatment. By contrast the phagocytosis of radiolabelled aggregated $\mathrm{IgG}$ by RA MO did not differ from the uptake by control MOs. As in our own study, no correlation was demonstrable between clinical indices of RA activity and PA. We have demonstrated the importance of matching ages between patients and controls, as this may affect the results. In addition the finding that RA patients with vasculitis have low PA and patients without extra-articular complications have normal or enhanced $\mathbf{P A}^{8}$ suggests that a general RA population will include a wide range of PA, which could mask any differences from normal which would otherwise emerge. Enhanced PA appears to be a cellular phenomenon, as our own study and that of Hurst and $\mathrm{Nuki}^{8}$ used normal serum as an opsonin, but we cannot exclude the possibility of activation mediated by the patient's own serum prior to cell separation.
Further studies to examine the effects of RA serum on RA and control cells are in progress. As our results and those of Hoch and Schur ${ }^{11}$ suggest that steroids may influence MO phagocytic activity, the test could be used to evaluate potential antirheumatic drugs. Since enhanced PA is also associated with activation of other MO functions, including bacterial killing ${ }^{20}$ and the secretion of proteolytic enzymes, ${ }^{4}$ it would appear that some RA patients have a population of cells inappropriately stimulated and capable of releasing proteolytic enzymes which could degrade cartilage. This activation may be of importance in the pathogenesis of rheumatoid arthritis.

We thank Anne O'Dowd and Robert McNaught for technical assistance and Maureen Tucker for typing the manuscript.

\section{References}

1 Denman A M. The macrophage, inflammation and rheumatoid arthritis. In: Panayi G S, Johnson P M, eds. Immunopathogenesis of rheumatoid arthritis. Surrey: Reedbrooks, 1979: 123.

2 Muirden K D. Lysosomal enzymes in synovial membrane in rheumatoid arthritis: relationship to joint damage. Ann Rheum Dis 1972; 31: 265-71.

3 Dayer J M, Robson D R, Krane S M. Prostaglandin production by rheumatoid synovial cells: stimulation by a factor from human mononuclear cells. J Exp Med 1977; 145: 1399-404.

4 North R J. The concept of the activated macrophage.J Immunol 1978; 121: 806-9.

5 Theofilopoulos A N, Carson D A, Tavassoli M, et al. Evidence for the presence of receptor for $\mathrm{C} 3$ and $\mathrm{IgG}$ Fc on human synovial cells. Arthritis Rheum 1980; 23: 1-9.

6 Fell H B, Jubb R W. The effect of synovial tissue on the breakdown of articular cartilage in organ culture. Arthritis Rheum 1977; 20: 1359-71.

7 Turner R A, Schumacher H R, Myers A R. Phagocytic function of polymorphonuclear leukocytes in rheumatic diseases. $J$ Clin Invest 1973; 52: 1632-5.

8 Hurst N P, Nuki G. Evidence for defect of complementmediated phagocytosis by monocytes from patients with rheumatoid arthritis and cutaneous vasculitis. $\mathrm{Br} M e d \mathrm{~J}$ 1981; 282: 2081-2.

9 Wynne K M, Dieppe P A, Scott J, Huskisson E C. Cellular phagocytic studies in rheumatoid arthritis patients treated with levamisole. Ann Rheum Dis 1981; 40: 382-7.

10 Bar-Eli M, Ehrenfeld M, Litvin Y, Gallily R. Monocyte function in rheumatoid arthritis. Scand J Rheumatol 1980; 9: 17-23.

11 Hoch S, Schur P H. Monocyte receptor function in patients with rheumatoid arthritis. Arthritis Rheum 1981; 24: 1268-77.

12 Gemmell C G, Steven M M, Sturrock R D. Phagocytosis and killing of bacteria by monocytes of patients with rheumatoid arthritis. In: Easman C S F, Gaya H, eds. Proceedings of the second international symposium on infection and the immunocompromised host. London: Academic Press, in press.

13 Peterson P K, Verhoef J, Sabbath L D, Quie P G. Kinetics of phagocytosis and bacterial killing by human polymorphonuclear leukocytes and monocytes. J In fect Dis 1977; 136: 502-9.

14 Boyum A. Separation of leukocytes from blood and bone marrow. Scand J Clin Lab Invest 1968; 21: suppl 97.

15 Verhoef J, Peterson P K, Quie P G. Kinetics of staphylococcal opsonization, attachment, ingestion and killing by human polymorphonuclear leukocytes: a quantitative assay using $\left[{ }^{3} \mathrm{H}\right]$ thymidine labelled bacteria. J Immunol Methods 1977; 14: 303-11. 
16 Siegel S. Non parametric statistics for the behavioural sciences. Tokyo: McGraw-Hill, Kogakusha, 1956.

17 Hurst N P, Nuki G. Abnormalities of monocyte C3b and Fc receptor phagocytic function in SLE. Arthritis Rheum 1982; 25: S74.

18 Svensson B. Occurrence of deficient monocyte yeast cell phagocytosis in presence of rheumatic sera. Scand J Rheumatol 1980; 31 (suppl): 21-7.
19 Svensson B, Norberg R, Torskensson R. Effects of cryoglobulins and aggregated $\mathrm{IgG}$ on in vitro monocyte phagocytosis. Scand $J$ Rheumatol 1978; 31 (suppl): 57-65.

20 Steven M M, Sturrock R D, Gemmell C G. Bacterial killing by mononuclear phagocytes in rheumatoid arthritis. Presented to the Combined Meeting of the Medical Research Society and the Scottish Society for Experimental Medicine. Edinburgh. Clin Sci 1982; 63: 31-2 (abstr). 